\title{
Potential Impact of Large Scale Abstraction on the Quality of Shallow Groundwater for Irrigation in the Keta Strip, Ghana
}

\author{
B. K. Kortatsi ${ }^{1 *}$, E. Young ${ }^{2}$ and A. Mensah-Bonsu ${ }^{3}$ \\ ${ }^{1}$ Groundwater Division, CSIR-Water Research Institute, P.O. Box M32, Accra, Ghana \\ ${ }^{2}$ Centre for Arid Zone Studies, University of Wales, Bangor Gwynedd, LL57 2UW, UK \\ ${ }^{3}$ ASIP Project Management Unit, P.O. Box M37, Accra, Ghana \\ *Corresponding author
}

\begin{abstract}
The potential impact of large-scale groundwater abstraction on the shallow groundwater and crop production within the Keta Strip was examined. The assessment was based on geophysical data, data on groundwater quality, soils, irrigation water requirement and hydrogeology of the Strip. The results indicate that the shallow groundwater can support only medium to high salt tolerant crops. This is consistent with the medium salt tolerant crops especially shallot and onion currently grown in the area. Large-scale irrigation of the Strip will require at least $2 \mathrm{x} 10^{7}$ $\mathrm{m}^{3}$ of water during the dry season. Abstraction of such large volume of water from the shallow aquifer will result in the lowering of water table by approximately $1.0 \mathrm{~m}$ per year. The consequence of this will be the up coning of the fresh/saline water interface probably by as much as 4.7 $\mathrm{m}$, resulting in salinisation of the fresh water lenses particularly around the lagoon end where most of the shallot farms are situated. Apart from up conning, salinisation may result from ingress of brackish/saline water from the lagoon and sea into the fresh water lenses. Though post irrigation rainfall will be adequate to nullify the water table depression, once the fresh water is contaminated, it is extremely difficult to decontaminate. Consequently, the shallow groundwater will evolve from medium through high to very high salinity hazard to crops. Specific ions toxicity will also increase due to increment in the concentrations of individual ions. Thus, the previously freshwater will become unsuitable for the production of even high salt tolerance crops. This will effectively halt the lucrative shallot and other vegetable farming in the Keta Strip and thus signify socio-economic disaster for the Keta Strip in particular and Ghana in general.
\end{abstract}

\section{Introduction}

The Keta Strip has been a zone of intensive agriculture since the beginning of the 19th century and is indeed the main area for shallot production in Ghana. Crop production is mainly either rain-fed or by low level of irrigation using the shallow groundwater. The mode of groundwater abstraction is mainly fetching water from hand-dug wells using buckets or watering cans. However, a few low yield pumps were recently introduced.

Due to the dwindling fishing industry in the Keta Strip, particularly in the Keta lagoon, greater attention has been shifted to cash crops, mainly shallot and vegetable production. Almost all available lands within the Keta Strip not occupied by houses are utilized for crop production. Significant increase in crop production would not, however, be achieved if the present mode of abstraction and irrigation were maintained. Fadama Irrigation Programme (MOFA, 1997) estimated 30\% increase in crop production by increasing the number of wells and if electrical pumps were used to irrigate. In line with this, the Agricultural Sector Investment Project (ASIP) provided funds to farmers' groups for the construction and mechanisation of about 1500 new hand-dug wells and those already in existence within the Keta Strip. Tube well construction and mechanization were also encouraged.

In 1996, the consultants working on DFID-funded NRSP Land/Water Interface project (R6777), known as 'Participatory approaches to the management of the coastal zone ecosystem in Ghana, expressed concern over the construction of several mechanized wells in the Keta Strip without adequate monitoring (Robinson, 1998). Their concern was based on the fact that the freshwater was sitting on a large mass of saline water. Any disturbance of the fragile fresh/saline water interface by uncon-trolled large-scale abstraction could erode the fresh water base of the strip. ASIP, sub-sequently suspended the well construction programme for impact assessment of large-scale abstraction on shallow ground water within the Strip to be carried out. The CSIR-Water Research Institute was, therefore, requested by ASIP to carry out the assessment. The objective of this paper is to use part of the data generated during the impact assessment to evaluate the potential impact of large-scale shallow groundwater abstraction on crop production.

Description of the study area

\section{Materials and methods}

The Keta Strip lies between the Keta lagoon to the north and the Gulf of Guinea to the south (i.e. the area within latitudes $5^{\circ} 47^{1}$ and $5^{\circ} 55^{1} \mathrm{~N}$ and longitudes $0^{\circ} 53^{1}$ and $1^{\circ} 0^{1} \mathrm{E}$ ). It occupies approximately $45 \mathrm{~km}^{2}$ of land surface. A map of the Keta Strip is shown in Fig. 1.

The Strip has a dry equatorial climate with a mean temperature of $28{ }^{\circ} \mathrm{C}$. There are two rainfall maxima (June and September). The peak, however, occurs in June. The mean annual rainfall is between $740 \mathrm{~mm}$ and $890 \mathrm{~mm}$ while the humidity varies from $60 \%$ in the dry season to $75 \%$ in the wet season (Dickson \& Benneh, 1980). The vegetation is mainly red mangrove, which is used as fuel wood. The soil consists mainly of coastal savanna Ochrosols, sodium Vleisols and coastal sand. The coastal savanna Ochrosols and coastal sand are pale yellow sand and are often without 
a top layer of humus or organic matter. The sodium Vleisols are alkaline and are found in close association with the Keta lagoon. These are black and dark grey in colour and become soggy in the wet season, but lose most of their moisture in the dry season (Dickson \& Benneh, 1980). The shallots are mainly grown in the sodium Vleisols, since these are soggy during the rainy season. Production of shallot is mainly during the dry season.

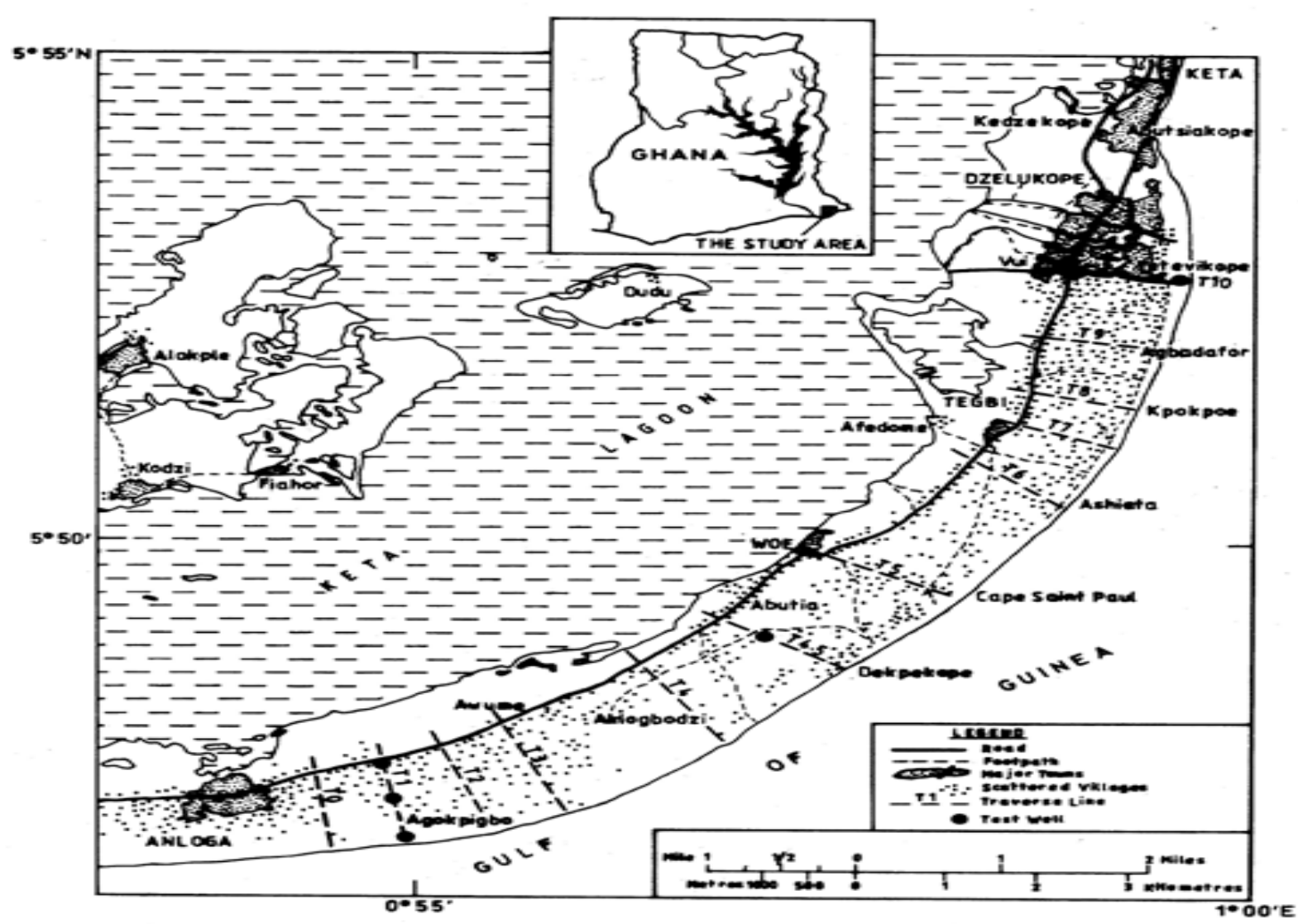

Fig. 1. Map of Keta Strip showing traverse lines and test wells position

The shallow aquifers occur in the Recent Sediments, consisting mainly of beach sand, gravels, silt and clay. These drift deposits are medium grained with gravels underneath. Closer to the lagoon, the formation is fine-grained sand interbedded with clays. The Recent Sediments vary in thickness from 30 m to over $100 \mathrm{~m}$ (Kesse, 1985).

\section{Data collection}

The data collection involved geophysical investigations (combined electromagnetic profiling and vertical electrical sounding) using Geonics EM34-3 and Abem SAS300C Terrameter to determine the aquifer (fresh water lens) geometry, test drilling at selected sites to enable formation and hydrochemical logging, step-drawdown and constant discharge pumping test were carried out to determine the hydraulic conductivity and transmissivity of the formation. There are available many excellent reviews of these techni-ques for hydro-geological data collection, and the reader is referred to a few of these (Acworth, 1987; Barker, White \& Houston, 1992; Beeson \& Jones, 1988; Hazell, Cratchley \& Preston, 1992; Wright, 1992; Karanth, 1987).

Two water samples were collected from each test well in pre-acid treated $1 l$ high density plastic bottles. Before sampling, pumping was carried out for an average of $10 \mathrm{~min}$. to prevent sampling stagnated water in the well (Gale \& Robins, 1989). The samples for metal analyses were acidified to $p \mathrm{H}$ value less than 2.0 using reagent grade nitric acid. The second samples for anion analysis were left unpreserved. Additionally, unstable physico-chemical parameters such as $p \mathrm{H}$, temperature, conductivity and alkalinity were measured at the wellhead with HACH test kit. Physicochemical analysis was carried out using standard methods for the examination of water and waste water (APHAWWA-WPCF, 1994). 
Geometry of shallow aquifer

\section{Results and discussion}

Typical Geonics EM34-3 profile along a traverse from the lagoon to the sea along traverse T5 (Fig. 1), the mid portion of the Keta Strip is illustrated in Fig. 2a. Similarly, the VES response at a point along the same profile is illustrated in Fig. 2b. It can be seen from Fig. 2a that the dipole response curves are relatively low $\left(<100 \mathrm{mS} \mathrm{m}^{-1}\right)$ in the middle portion but close to both ends (i.e. 0-100 m and 1900-2100 m) the horizontal dipoles (20 m-HD and $40 \mathrm{~m}$ HD) $>100 \mathrm{mS} \mathrm{m}^{-1}$ while the vertical dipole responses were negative. Groundwater is usually fresh with conductivities typically in the range $10-100 \mathrm{mS} \mathrm{m}^{-1}$ (Shedlock, 1987). The negative response of the vertical dipoles only signified that conductivity values were higher than the $700 \mathrm{mS} \mathrm{m}^{-1}$, the linear range of the Geonics EM34-3 (Geonics, 1998). According to Barker, White \& Houston (1992), the depth of investigation of the 40 vertical dipole (40 m-VD) is $34.8 \mathrm{~m}$. Thus, Fig. 2a suggested that the fresh-water depth along this traverse was shal-lower than $34.8 \mathrm{~m}$ near the sea and the lagoon ends but deeper in the middle than $34.8 \mathrm{~m}$.

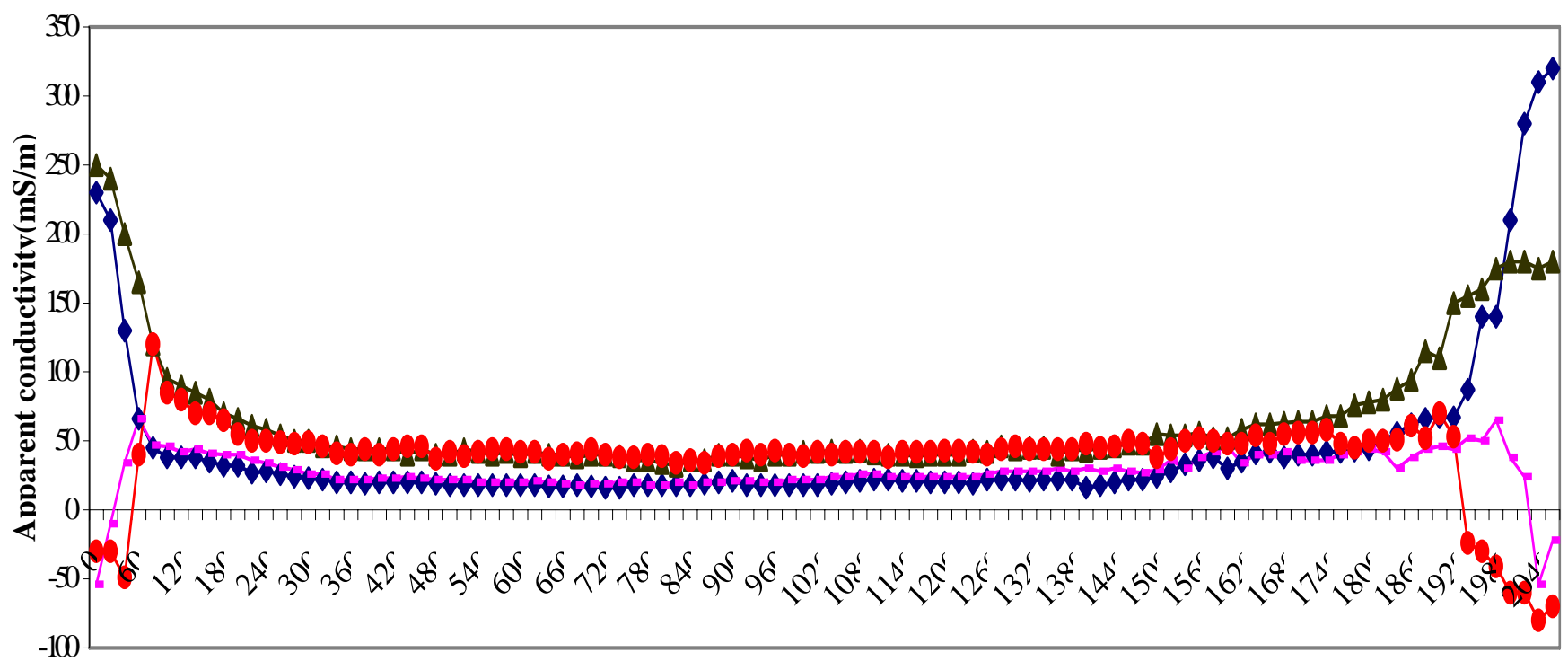

Dstancedongtravese(fromLagonsea) (n)

$-20 \mathrm{mH}+20 \mathrm{~m}+\mathrm{VD}-40 \mathrm{~m}+\mathrm{D}-\bullet-40 \mathrm{~m}+\mathrm{VD}$

Fig. 2a. Typical Geonics EM34-3 profile along a traverse (T5) from the lagoon to the sea

To ascertain the actual depths to the freshwater/saline water interface, series of vertical electrical soundings were carried out. VES result at a point (1000 $\mathrm{m}$ from the lagoon) along traverse T5 is illustrated in Fig. 2b. The freshwater/saline water interface at this point occurred at an appro-ximate depth of $36 \mathrm{~m}$ (depth to very low resistivity layer). The cross section along traverse T5 as delineated by VES at several locations is shown in Fig. 3. For the results of other cross sectional deter-minations and the freshwater lens geometry, the reader is referred to Kortatsi \& Agyekum (1999). Generally, however, the fresh water lens aquifer is shallower at both the lagoon and sea ends and is relatively deep in the middle portion with skewness towards the sea. The mean depth to the interface is 10-15 m while the maximum depth is just over 48 m (Robinson, 1998; Kortatsi \& Agyekum, 1999). 


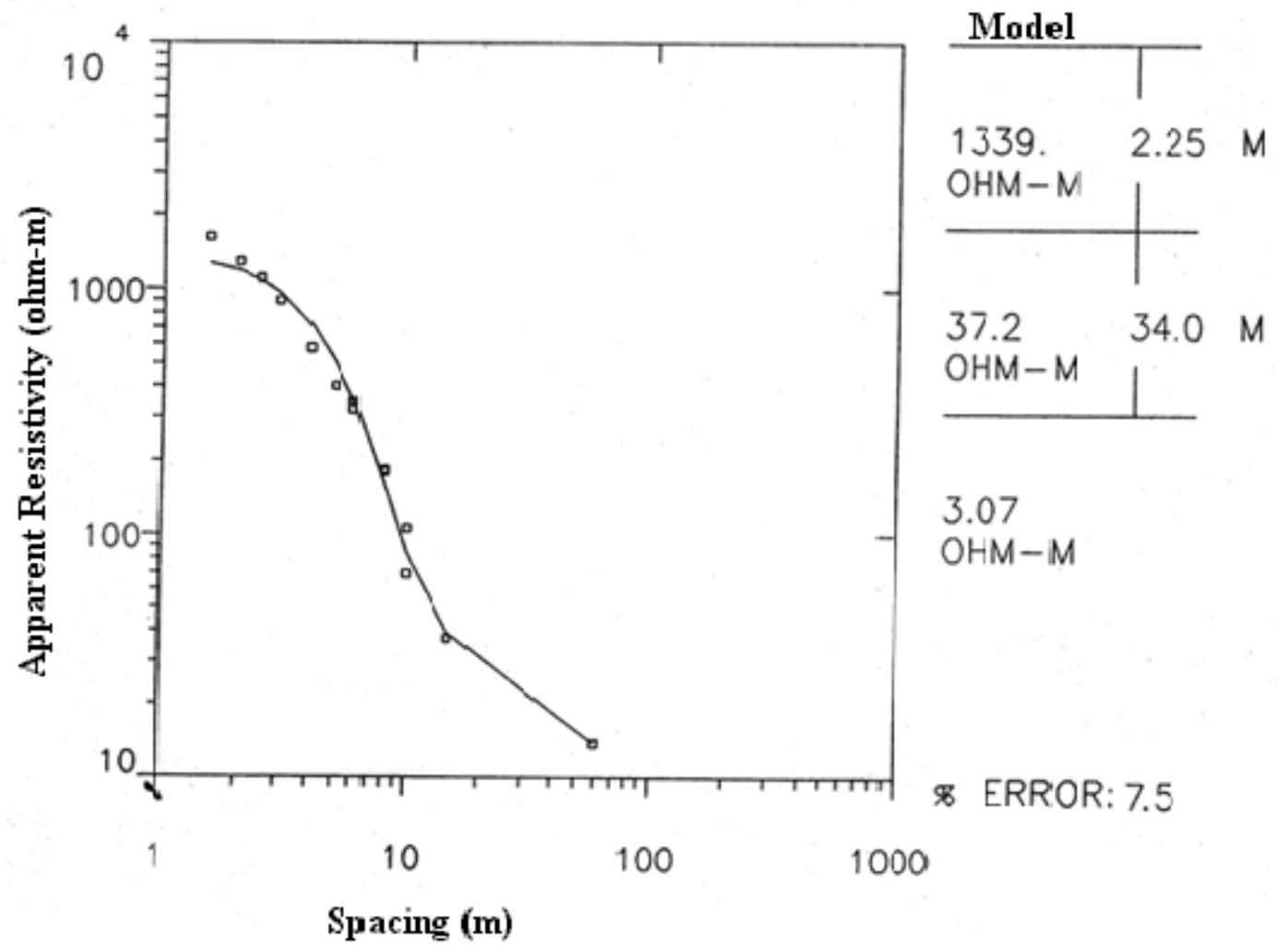

Fig. 2b. VES response curve and analysed results at 1000m mark along traverse T5

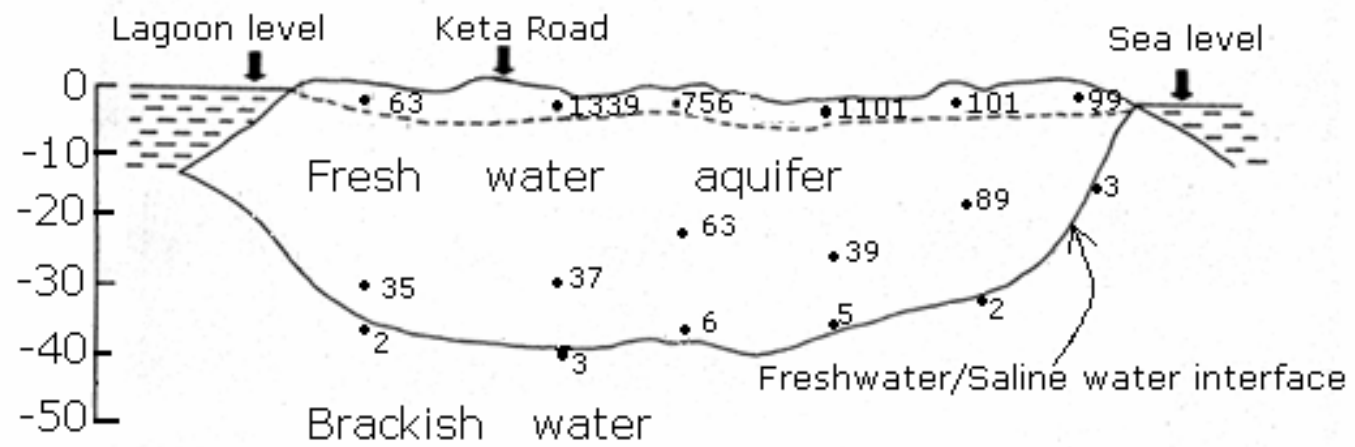

- Resistivity values (ohm-m)

$0200400 \mathrm{~m}$

Fig. 3. Cross section along traverse T5.

Water requirement for large scale irrigation of the Keta Strip

Keta Strip is a well-built area. Assuming a conservative estimate of only $46 \%$ ( $\left.20.7 \mathrm{~km}^{2}\right)$ of land area available for crop production, then the optimum amount of water required for approximately 7 months of irrigation per year is 2.0 $\times 10^{7} \mathrm{~m}^{3}$. This is based on an average minimum of $1.6 \times 104 \mathrm{~m}^{3}$ ha- 1 per year of water needed for irrigation in the Keta Basin (Nii Consult, 1997). 
Consequences of large scale water withdrawal for irrigation

Lowering of water table. One of the major effects of large scale pumping on closely spaced wells is overlap of cone of depression or well interference (Fig. 4). According to the principle of superposition, the drawdown in the interfering wells and that at any point within the area of influence is equal to the sum of drawdown component of each individual wells (Freeze \& Cherry, 1979; Karanth, 1994). As illustrated in this diagram, the drawdown from individual wells $\left(\mathrm{s}_{1}, \mathrm{~s}_{2}, \mathrm{~s}_{3}\right.$ etc.) adds up to produce a compo-site drawdown cone. This then results in the general lowering of the water table. Although well spacing in the Keta Strip was adequate and pumping test did indicate any interference effect, had ASIP constructed the 1500 wells well spacing in most cases would be less than $100 \mathrm{~m}$ resulting in well interference. Assuming a close system (i.e. no rainfall and very minimal irrigation return, no up coning of brackish water) and porosity value of $40 \%$ (fine-medium grained sand), the abstraction of $2.0 \times 10^{7} \mathrm{~m}^{3}$ of water to irrigate would lower the water table by approximately $1.0 \mathrm{~m}$ during the dry season. The consequence of this would be the ingress of saline water from both the lagoon and the sea into the fresh water lens.

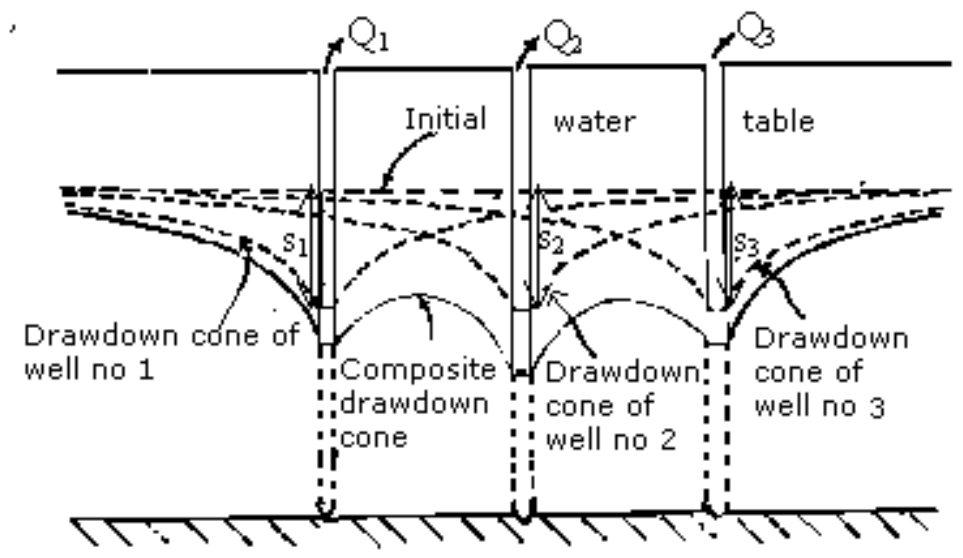

Fig. 4. Drawdown and composite drawdown cones of three wells pumping simultaneously.

Upconing of fresh/saline water interface. A second major effect of large scale pumping of fresh water for irrigation in the Keta Strip would be the upconing of the freshwater/saline water interface. The approximate height (z) of the cone at the well may be estimated from the Ghyben-Herzberg relation (Ghyben,1888; Herzberg, 1901) as follows:

$$
z=\frac{\rho_{f} s_{w}}{\rho_{s}-\rho_{f}}
$$

where $S_{w}=$ drawdown in a water-table aquifer, $P_{5}=$ Density of fresh water, $P_{1}=$ Density of sea water.

The position of the moving interface in response to the withdrawal of fresh water by shallow wells penetrating a short distance above the interface in a coastal aquifer is given by equation (2) (Dagan \& Bear, 1968):

$$
z_{t}=\frac{\rho_{f} Q}{2 \pi\left(\rho_{s}-\rho_{f}\right) K_{x} d}\left[1-\frac{2 \rho_{f} h_{w} \theta}{2 \rho_{f} d \theta+\left(\rho_{s}-\rho_{f}\right) K_{z} t}\right]
$$

where $Z_{t}=$ rise of apex of cone at time $t, Q$ = discharge of well, $\mathrm{d}=$ depth of interface below the bottom of the well, before commencement of pumping, $\mathrm{K}_{\mathrm{x}}=$ hydraulic conductivity in horizontal direction, $\mathrm{K}_{\mathrm{z}}=$ hydraulic conductivity in vertical direction, $\theta=$ porosity, and $\mathrm{t}=$ time since the start of pumping.

At equilibrium, that is when $t=$, the equilibrium height $\mathrm{z}$ of the cone is given by equation (3) as: 


$$
Z_{\infty}=\frac{\rho_{f} Q}{2 \pi\left(\rho_{s}-\rho_{f}\right) K_{\chi} d}
$$

Assuming only the 1500 ASIP wells (wells already exist in the area) are used in irrigating the available farmlands then each well is expected to supply $73.1 \mathrm{~m}^{3}$ daily during the dry season to accomplish the minimum water requirement for irrigation. The median depth of hand-dug wells in the Keta Basin is $5 \mathrm{~m}$ (Water Resources Research Institute, 1993) and the median depth to the fresh water/saline water interface is $10.3 \mathrm{~m}$ (Kortatsi \& Agyekum, 1999). Thus, on average, the base of each well is $5 \mathrm{~m}$ above the fresh/saline water interface. The hydraulic conductivity value of the fine medium sand, which predominates in the Keta Strip, is $20 \mathrm{md}^{-1}$ (Water Resources Research Institute, 1993). Therefore, using equation (3) and taking a daily yield of each well as $73.1 \mathrm{~m}^{3}$, the upconing per well per year will be $4.7 \mathrm{~m}$. This implies that approximately half the number of wells will have the fresh/saline water interface only $0.3 \mathrm{~m}$ below their bottom at the end of one year. The fresh/saline water interface is not sharp but diffused and fluctuates due to changes in tidal and potentiometric level. Consequently, the area around the lagoon where the interface is generally less than the median well depth will experience the ingress of brackish water into the wells.

Concentration irrigation return water. Another source of salinisation of the fresh water lenses is by irrigation return water. Irrigation water is concentrated through evapotranspiration anytime the fresh water comes to the surface and is exposed to the weather. Therefore, as abstracted water returns to the water table as irrigation return water, its TDS is higher than what it was when it was first abstracted. However, due to the high permeability of the medium sand, the time the water spends on the surface before its return may be short and, therefore, the increment in TDS as a result of con-centration by means of evapotran-spiration or irrigation return water may only be marginal.

Flushing of saline water. The rainfall in the built up area in the Keta Strip is largely harvested for domestic purposes. Assuming, therefore, that all rainfall is either harvested directly or if it has escaped direct harvesting and reached the water table is abstracted by domestic wells, then only the rainfall outside the build-up area will contribute significantly to fill the deficit created by pumping. Supposing due to the flat topography and high permeability of the sand, run-off and evapotranspiration of rainwater is insignificant and porosity of the medium sand is $40 \%$, the water table rise due to rainfall (mean annual rainfall of the Strip is $900 \mathrm{~mm}$ ) is approximately $1.0 \mathrm{~m}$ per year. Thus, the deficit that will be created by large-scale abstraction will be taken care of by rainfall the following season. Nonetheless, once salinisation has occurred, it is extremely difficult to return the water to freshness.

\section{The quality of shallow groundwater}

The summary of the physico-chemical parameters of the shallow groundwater of the Keta Basin is presented in Table 1. The chemical characterization of the shallow ground-water of the Keta Strip using the expanded Durov diagram is shown in Fig. 5. Three main water types occur in the Strip. These are $\mathrm{CaCl}_{2}, \mathrm{MgCl}_{2}$ and $\mathrm{NaCl}$. These waters have total dissolved solid (TDS) levels in the range 180-2430 $\mathrm{mg} \mathrm{l}^{-1}$ with a mean value of $615.8 \mathrm{mg} \mathrm{l}^{-1}$ (WRRI, 1992). The low TDS $\mathrm{NaCl}$ waters are mainly meteoric waters derived from sea spray (Aerosols). Near the coast, rain is primarily a sodium chloride solution (Berner \& Berner, 1987; Hounslow, 1995). The relatively higher TDS CaCl, $\mathrm{MgCl}_{2}$ and $\mathrm{NaCl}$ waters signify some degree of seawater intrusion into the fresh water lenses. $\mathrm{Ca}^{2+}$ and $\mathrm{HCO}_{3-}$ often dominate fresh water, and in seawater $\mathrm{Na}+$ and $\mathrm{Cl}^{-}$are the dominant ions. When seawater intrudes into coastal fresh water aquifer an exchange of cations takes place. Thus, the exchanger takes up $\mathrm{Na}^{+}$, and $\mathrm{Ca}^{2+}$ is released. The water quality, thus, changes from $\mathrm{NaCl}$ to $\mathrm{CaCl}_{2}$ type water (Appelo \& Postma, 1999).

TABLE 1

Summary of physico-chemical parameters of the shallow groundwaters in the Keta Strip

$\begin{array}{lrrr}\text { Parameter } & \text { Range } & \text { Mean } & \text { St. deviation } \\ & & & \\ \text { PH (unit) } & 5.1-7.2 & 6.6 & 0.4 \\ \text { Temperature }\left({ }^{\circ} \mathrm{C}\right) & 28.5-29.8 & 29.4 & 0.3 \\ \text { Conductivity }(\mu \mathrm{S} / \mathrm{cm}) & 200.0-8300.0 & 684.3 & 470.2 \\ \text { Sodium }\left(\mathrm{mg} \mathrm{l}^{-1}\right) & 17.1-196.2 & 68.5 & 40.8 \\ \text { Potassium }\left(\mathrm{mg} \mathrm{l}^{-1}\right) & 0.5-27.1 & 14.9 & 6.0 \\ \text { Calcium }\left(\mathrm{mg} \mathrm{l}^{-1}\right) & 1.3-202.9 & 21.0 & 35.8 \\ {\text { Magnesium }\left(\mathrm{mg} \mathrm{l}^{-1}\right)}_{\text {Iron }\left(\mathrm{mg} \mathrm{l}^{-1}\right)}^{1.7-10.7} & 8.8 & 21.8 \\ \text { Chloride }\left(\mathrm{mg} \mathrm{l}^{-1}\right) & 0.0-2.5 & 214.7 & 0.4 \\ \text { Sulphate }\left(\mathrm{mg} \mathrm{l}^{-1}\right) & 57.9-1239.0 & 192.1 & 192.1 \\ \text { Bicarbonate }\left(\mathrm{mg} \mathrm{l}^{-1}\right) & 0.3-242.0 & 25.5 & 43.4 \\ \text { Nitrate- }\left(\mathrm{mg} \mathrm{l}^{-1}\right) & 8.0-236.0 & 58.2 & 49.1 \\ & 0.0-173.0 & 11.2 & 25.9\end{array}$




$\begin{array}{rrr}0.1-0.4 & 0.1 & 0.1 \\ 7.75-507.5 & 102.1 & 90.7 \\ 180.0-2430.0 & 615.8 & 423.2 \\ 8.0-236.0 & 58.1 & 49.1 \\ 40.0-663.6 & 190.9 & 140.0\end{array}$

$N B$ : All values except $p \mathrm{H}$ are in $\mathrm{mgl}^{-1}$

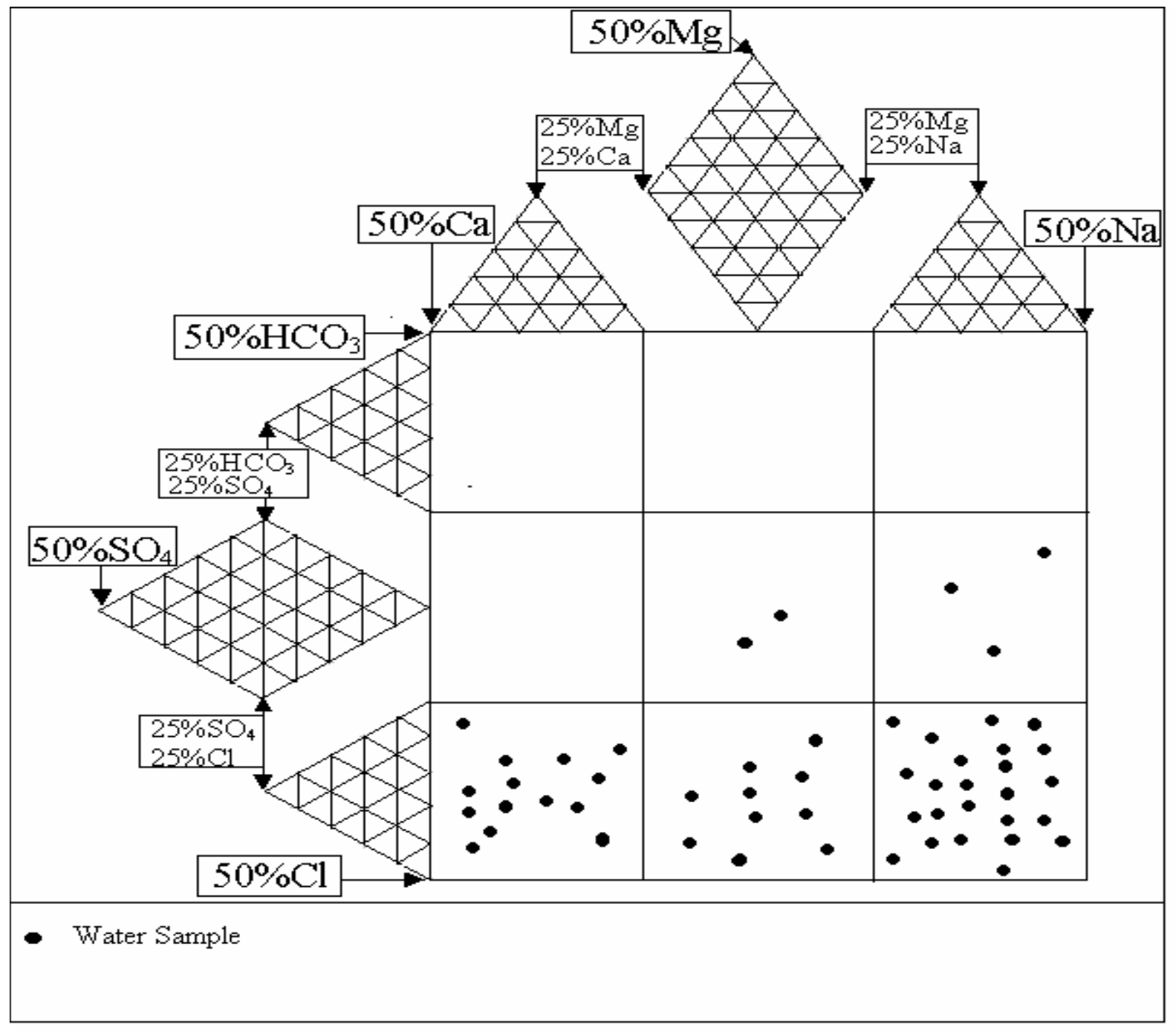

Fig. 5. Expanded Durov diagram illustrating main water types of the fresh water lens

Suitability of the quality of the shallow groundwater for crop production

The classification of the shallow groundwater in the Keta Strip as irrigation water with respect to salinity and sodium hazards after US Salinity Laboratory Staff (1954) is presented in Fig. 6. Most of the water samples plotted in the zone designated C2-S1 and C3-S1 indicating that the shallow ground-waters generally have low sodium absorption ratio (SAR) and medium to high salinity hazard associated with them. The waters can, thus, support the growth of medium to high salt tolerate crops. The cash crops currently grown in the Keta Strip are mainly vegetables, notably shallot, onion, pepper, carrot, tomato and cabbage. On a minor scale cassava and maize are grown for subsistence. Table 2 presents the relative tolerance of crops (plants) to salinity of soil water. As evident from this Table, all the crops grown in the Keta Strip at the moment are medium salt tolerant crops. This is very consistent with the sort of crops that the shallow groundwaters can support. 


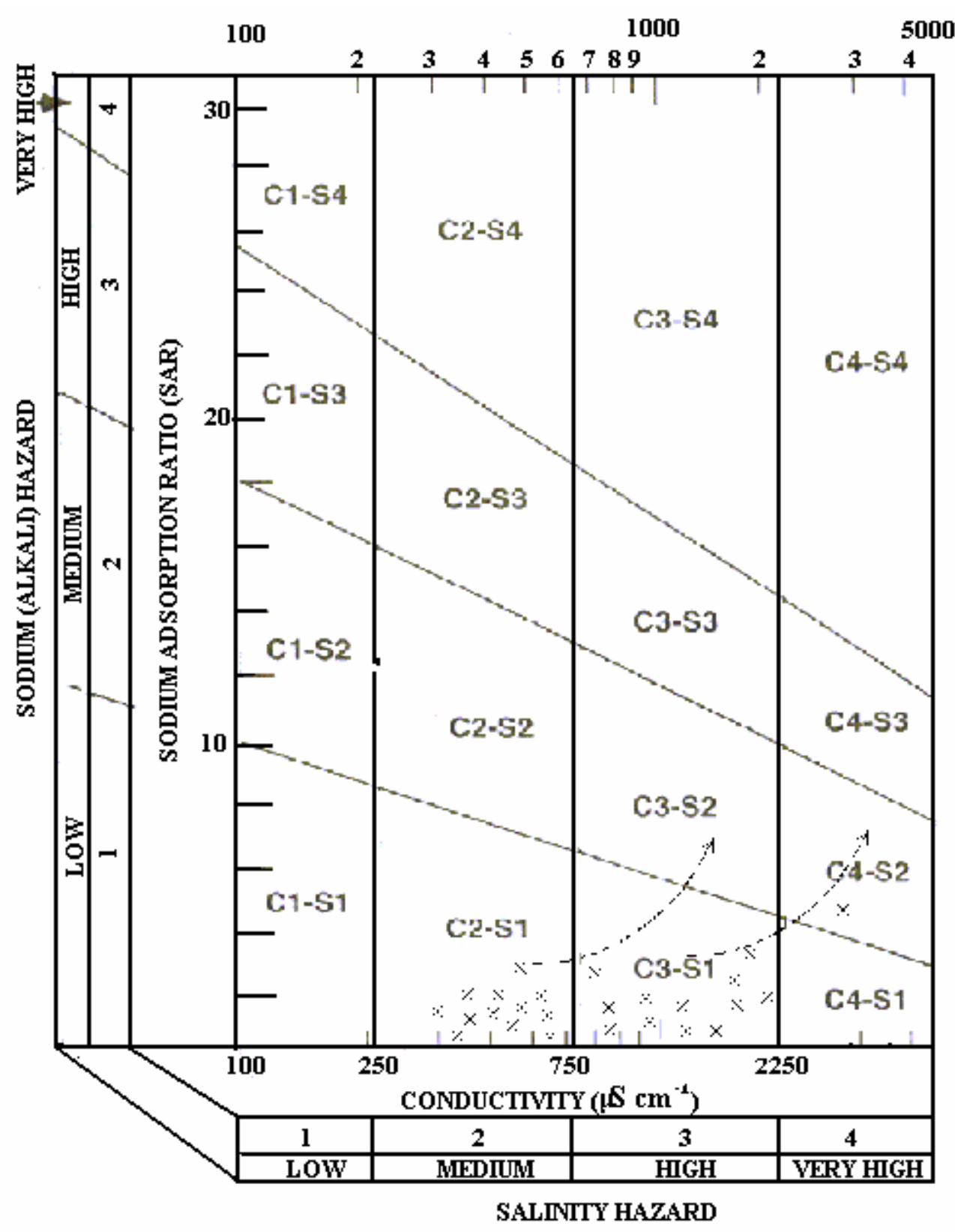

$\therefore$ Water sanple

$i^{3}$ Path of salinity evohution

Fig. 6. Classification of the shallow groundwaters with respect to Sodium adsorption ratio and salinity hazard

TABLE 2

Relative tolerance of some common crops/plants to salinity of soil water (after Bower, 1974). Those grown locally are in italic

High salt tolerance

Alkali sacation

Barley (grain)

Barley (hay)

Bernmida grass

Canada wildrye

Cotton

Nuttall alkaligrass

Rape

Rescue grass

Rhodes grass

Sugar beet

\section{Medium salt tolerance \\ Low salt tolerance}

Cabbage

Carrot

Castor bean

Cauliflower

Corn (field)

Cucumber

Lettuce

Oats (grain)

Onion (shallot)

Pepper

Potatoes
Alsike clover

Burnet

Field beans

Ladino clover

Meadow foxtail

Red clover

White Dutch clover 
Impact of increasing salinity on Agriculture (Crop production)

The hypothetical changes in the chemical composition of fresh water when mixed with sea water shown in Table 3 indicate that by mixing $10 \%$ and $20 \%$ of sea water with fresh water (mean concentration) changes the total concentration of the major ions $\left(\mathrm{Ca}^{2+}, \mathrm{Mg}^{2+}, \mathrm{Na}^{+}, \mathrm{K}^{+}, \mathrm{SO}_{4}^{2-}, \mathrm{Cl}^{-}, \mathrm{HCO}_{3}\right.$ ) from $373 \mathrm{mg} \mathrm{l}^{-1}$ to $3906 \mathrm{mg} \mathrm{l}^{-1}$ and $7441 \mathrm{mg} \mathrm{l}^{-1}$, respectively. Consequently, significant ingress of sea or brackish water into the fresh water lens as a result of largescale irrigation will increase the salinity of the fresh water aquifer lenses tremendously. Water samples that originally plotted in zone C2S1 (Fig. 4) may now move along the paths indicated in Fig. 4 through zone C3S1, C3S2 and plot in either C3-S3, C4-S3 or C4-S4. If this happens, the shallow groundwater can no longer support low SAR-medium to high salinity tolerant crops. The present cash crops in the Keta Strip (the vegetables), which are all medium salt tolerant crops can no longer be grown. Even high salt tolerant crops may be affected. In addition, special management for salinity control and chemical amendments may be required to replace exchangeable sodium. This means that the lucrative vegetable production may come to a halt. Additionally, cropping salt tolerant crops may be expensive and highly technical and, perhaps, beyond the means of the ordinary farmer. This will result in socio-economic disaster for the Keta Strip, in particular.

TABLE 3

Hypothetical mixing of fresh water from the Keta Strip with sea water

\begin{tabular}{|c|c|c|c|c|}
\hline \multirow[t]{2}{*}{ Parameter } & Fresh water $\left(\mathrm{mg} \mathrm{l}^{-1}\right)$ & Sea water $\left(\mathrm{mg} \mathrm{l}^{l^{-1}}\right)$ & $\begin{array}{c}\text { Mixture } 1\left(\mathrm{mg} \mathrm{l}^{-1}\right) \\
90 \% \text { freshwater }\end{array}$ & $\begin{array}{c}\text { Mixture } 2(\mathrm{mg} \\
80 \% \text { freshwate }\end{array}$ \\
\hline & Median values & $10 \%$ sea water & $20 \%$ sea water & \\
\hline $\mathrm{PH}$ & 7 & 6 & 6 & 6 \\
\hline $\mathrm{Ca}$ & 21 & 425 & 61 & 102 \\
\hline $\mathrm{Mg}$ & 1 & 1398 & 140 & 280 \\
\hline $\mathrm{Na}$ & 69 & 10875 & 1149 & 2230 \\
\hline K & 6 & 404 & 45 & 85 \\
\hline $\mathrm{SO}_{4}$ & 26 & 2796 & 303 & 580 \\
\hline $\mathrm{Cl}$ & 192 & 19679 & 2141 & 4089 \\
\hline $\mathrm{HCO}_{3}$ & 58 & 146 & 67 & 75 \\
\hline
\end{tabular}

\section{Conclusion}

The studies have shown that large-scale irrigation of all available agricultural lands will need a minimum of $2.0 \times 10^{7}$ $\mathrm{m}^{3}$ water through the dry season. Abstraction of this amount of the shallow groundwater in the dry season will depress the water table by at least $1 \mathrm{~m}$. The depression in the water table may result in upward movement of the fresh/saline water interface and the ingress of saline water from both the sea and the lagoon into the fresh water lenses. The mixing of even $10 \%$ of sea or brackish water with the fresh groundwater will increase the total dissolved solid content of the fresh water (mixture) by ten fold.

Increasing the salinisation of the fresh water lens aquifers will, therefore, lead to higher salinity, sodium adsorption ratio and specific ions hazards to crops currently produced in the Keta Strip. Though the post irrigation rainfall may just be enough to flush the saline water, once the fresh water lens gets contaminated it becomes extremely difficult to deal with. The shallow groundwater will, therefore, no longer be suitable for medium salt tolerant crops currently grown in the area, effectively halting the lucrative shallot and other vegetables farming in the Keta Strip. This will be socio-economic disaster for the Keta Strip, in particular and Ghana in general.

\section{Acknowledgement}

The paper is an output from a consultancy project undertaken by the Water Research Institute (WRI) for the Ministry of Food and Agriculture (MOFA). The authors are very grateful to MOFA for funding the project. They are also grateful to technicians from the Groundwater Division of the WRI for their valuable contribution during the field data collection. 


\section{References}

Acworth R. I. (1987). The development of crystalline basement aquifers in a tropical environment. Q. Jl of Engng Geol. 20: 265-272.

APHA-WWA-WPCF. (1994). Standard methods for the examination of water and wastewater. American Public Health Association (APHA), Washington DC, USA.

Appelo C. A. J. and Postma, D. (1999). Chemical analysis of groundwater. Geochemistry, groundwater and pollution. AA Balkema Rotterdam/Brookfield.

Ayers R. S. (1975). Quality of Water for Irrigation. Proc. Irrig. Drain. Div., Special. Conf., Am. Soc. Civ. Engng. August 23-15, Logan Utah. pp. 24-56.

Barker R. D., White, C. C. and Houston, J. T. F. (1992). Borehole siting in an African accelerated drought relief project; In The Hydrogeology of Crystalline Basement Aquifers in Africa. (E. P. Wright and W. G. Burgess, ed.), pp. 183-200. London: Geological Society Geological Society Special Publication No. 66.

Beeson S. and Jones, C. R. C. (1988). The combined EMT/VES Geophysical method for siting boreholes. Ground Wat. 26: 54-63.

Berner E. K. and Berner R. A. (1987). The Global Water Cycle. Englewood Cliffs, NJ: Prentice-Hall,

Dagan G. and Bear J. (1968). Solving the problem of local interface upconing in a coastal aquifer by the method of small perturbations, J. Hydraul. Res. 6 (1): 15-44.

Dickson K. B and Benneh, G. (1980). A New Geography of Ghana. London: Longmans Group Ltd.

Freeze R. A. and Cherry A. J. (1979). Groundwater, Englewood Cliffs, New Jersey: Prentice-Hall Inc.

Gale I. N. and. Robins N. S. (1989). The sampling and monitoring of groundwater quality. Br. Geol. Surv. Hydrogeol. Rep. No. 89/37.

Ghyben W. B. (1888). Nota in verband met de voorgenomen putboring nabij Amsterdam. Tijdschrift van Let Koninklijk Inst. Van Ing.

Hazell J. R. T, Cratchley,C. R. and Preston, A. M. (1992). The location of aquifers in crystalline rocks and alluvium in northern Nigeria using combined electromagnetic and resistivity techniques. Q. Jl Engng Geol. 21: 159-175

Herzberg A. (1901). Die Wasserversorgung einiger Nordseebader. J. Gasbeleucht. Wasserversorg 44: 815-819.

Hounslow A. W. (1995), Water Quality Data. Analysis and interpretation. Boca Raton, New York: Lewis Publishers.

Karanth K. R. (1994). Groundwater Assessment Development and Management. New Delhi: Tata McGraw-Hill Publishing Company Limited

Kesse G. O. (1985). The mineral and rock resources of Ghana. Rottendam/Boston: A.A. Balkema.

Kortatsi B. K. and Agyekum W. A. (1999). Final report on environmental impact assessment of large scale groundwater abstraction in the Keta Strip of the Volta Region of Ghana. Accra: Agricultural Sector Investment Project (ASIP). Ministry of Food and Agriculture (MOFA). Government of the Republic of Ghana

MOFA (1997). Fadama Irrigation Programme; Project Proposals for the establishment of a pilot shallow tube well irrigation scheme at Okyereko, Tordzienu/Hikpo and Anyakpor in the Central, Volta and Greater Accra Regions of Ghana respectively. Accra: Irrigation Development Authority.

Nii Consult (1997). Ghana Water Management Study, Information Building Block Report, Volume 1. Accra: Ministry of Works and Housing/Danida.

Robinson G. S. (1998). A study of the Keta Strip Shallow Aquifer, Ghana. (MSc. Thesis.) Centre for Arid Zones Studies, University of Wales, Bangor.

Shedlock S. L. (1987). Borehole logging in Masvingo Province, Zimbabwe. Unpublished report of British Geological Survey, WD/OS/87/7

U. S. Salinity Laboratory Staff (1954). Diagnosis and improvement of saline and alkaline soil. U.S. Department of Agriculture Hand book No. 60, 160 pp.

Water Resources Research Institute (WRRI) (1993). Final report on the inventory and assessment of potential for hand dug wells in the Volta Region vol. 1-Main report. Accra Rural Drinking Water Supply and Sanitation Project in the Volta Region. Royal Danish Embassy (DANIDA).

Water Resources Research Institute (WRRI) (1992). Preliminary report on the inventory and assessment of potential for hand dug wells in the Volta Region. Vol. 1-Main report. Accra: Rural Drinking Water Supply and Sanitation Project in the Volta Region. Royal Danish Embassy (DANIDA).

Wright E. P. (1992). The hydrogeology of crystalline basement aquifers in Africa. In The Hydrogeology of Crystalline Basement Aquifers in Africa. (E. P. Wright and W. G. Burgess, ed.). London: Geological Society. Geological Society Special Publication No. 66, pp. 183-200. 